\title{
Does gender explain the relationship between occupation and suicide? Findings from a meta-analytic
} study

\author{
Milner A. $\mathrm{J}^{1}$, Spittal, M.S ${ }^{2}$, Pirkis $\mathrm{J}^{3}$, LaMontagne, A. D ${ }^{4}$.
}

1. McCaughey VicHealth Centre for Community Wellbeing, Melbourne School of Population and Global Health, The University of Melbourne

2. Centre for Health Policy, Melbourne School of Population and Global Health, The University of Melbourne, email: m.spittal@unimelb.edu.au

3. Centre for Mental Health, Melbourne School of Population and Global Health, The University of Melbourne, email: j.pirkis@unimelb.edu.au

4. Population Health Strategic Research Centre, School of Health \& Social Development, Deakin University, email: tony.lamontagne@deakin.edu.au

Corresponding author

Dr Allison Milner

McCaughey VicHealth Centre for Community Wellbeing

Melbourne School of Population and Global Health

University of Melbourne

Level 5, 207 Bouverie Street

Melbourne, VIC 3010, AUSTRALIA

allison.milner@unimelb.edu.au

Tel (international) +61-3-9035-9875

Fax (international) +61-3-9348-2832 


\begin{abstract}
This report investigated whether suicide risk by occupational groups differed for males and females. We examined this using a sub-set of articles examined in a recent meta-analysis and stratified by gender. For certain occupational groups, males and females had a similar risk of suicide (the military, community service occupations, managers, and clerical workers). There was some indication of gender differences for other occupations (technicians, plant and machine operators and ship's deck crew, craft and related trades workers, and professionals), although these did not reach statistical significance. These findings highlight the complexity of the relationship between occupation and suicide and suggest the possible role of a range of individual, workrelated and social-environmental risk factors that may differ for males and females.
\end{abstract}

Keywords: suicide, occupation, gender, meta-analysis, review 


\section{Introduction}

Gender is an important epidemiological factor in suicide research, as males and females have differing patterns and risk factors for this behaviour. In most countries the number of male suicides greatly exceeds female suicides, and males typically use more violent and lethal means to end their lives (Windfur \& Kapur, 2011).

Gender specific risks are all the more pertinent when the issue of occupational variations in suicide are considered. In a recent meta-analysis we showed that people in low skilled occupations (such as manual labor jobs) have a significantly higher risk of suicide than the general working-age population (Milner, Spittal, Pirkis, \& LaMontagne, 2013). This result may be indicative of the gender composition of the occupation group itself, as being male is an independent risk factor for both suicide and being employed in a low-skilled job (Forrest, 2014). In this case, elevated rates may actually be disguising an underlying greater vulnerability of males to suicide.

It is also possible that some occupations have higher rates of suicide than others because of factors that can operate independently of gender, such as socio-economic status (e.g., income, education) or issues connected to work and workplace itself, such as adverse working conditions, negative attitudes towards help-seeking, and stigma against mental illness (Milner et al., 2013). In this case, males and females may be equally impacted, and both will have high rates of suicide. Last, gender may modify the association between occupation and suicide, so that there are differing effects of occupation for females and males (Hawton, Clements, Sakarovitch, Simkin, \& Deeks, 2001; Lindeman, Laara, Hakko, \& Lonnqvist, 1996). An example of this is the higher risk of suicide among female (but not male) medical doctors compared to the general population (Hawton, Clements, Sakarovitch, Simkin, \& Deeks, 2001).

The aim of this brief report is to clarify the extent to which the relationship between occupation and suicide is different for males and females across studies. We hypothesised that (1) both males and females will have higher risk of suicide in low-skill occupations, and (2) there will be gender differences in suicide in higherskilled occupations such as medical professions (based on the research mentioned above). These hypotheses were tested using a subset of studies examined in our recent meta-analysis (Milner et al., 2013) by stratifying the study-specific estimates by gender.

\section{Methods}

The methods used for the meta analysis have been published previously (Milner et al., 2013) but are briefly summarized below. No ethics requirement was needed for this study as it used publically available, published data. All authors certify responsibility for this article and declare no conflicts of interest.

\section{Search strategy:}

The review was conducted according to the PRISMA guidelines (http://www.prisma-statement.org/). The search strategy targeted studies that reported information on suicide by occupation and used a number of computer based internet databases (PubMed, Web of Science, Proquest, and Scopus). The first author conducted the initial data searches. Subsequent data checking and searches were overseen by the third and fourth authors, and mismatches in classification of studies resolved by consensus. 
Eligibility criteria and selection of studies:

To be included in the meta-analysis, all studies had to report suicide mortality by occupational groups. Suicide is defined as any death where the cause of death or the contributory cause of death was identified as intentional self-harm by a coroner or similar body (Windfur \& Kapur, 2011). Preference was given to those studies able to provide information across representative populations (e.g., coverage across entire occupational groups), rather than smaller samples within specific populations. All effect size estimates were considered, including odds ratios (ORs), rate ratios (RRs), relative risks, proportionate mortality ratios (PMRs), and standardised mortality ratios (SMRs). Studies were included if we could extract this information as well as a measure of variability of this estimate (either the standard error or $95 \%$ confidence interval).

\section{Coding of occupation:}

Occupational grouping was assigned using major codes from the International Standard Classification of Occupations (ISCO) (version 2008).[6] These classifications included: category 1 (Managers, senior officials and legislators), category 2 (Professionals), category 3 (Technicians and associate professionals), category 4 (Clerical workers), category 5 (Service personnel such as police and sales workers), category 6 (Skilled agricultural and fishery workers), category 7 (Craft and related trades workers), category 8 (Plant and machine operators, and assemblers), and category 9 (Elementary occupations such as labourers and cleaners). Military occupations were coded 0 because these are unable to be classified according to skill level.

\section{Statistical analysis:}

To assess the effect of occupational skill level on risk of male and female suicide, separate random effects meta analyses were conducted for each occupational subgroup. The pooled subgroup results were presented on the exponential scale and presented as relative risks (RR). Heterogeneity in the effect size between studies was assessed through the $\mathrm{I}^{2}$ statistic. All analyses were conducted in Stata 12.1 using the "metan" commands (StataCorp, 2012).

\section{Results}

We identified a total of 1,290 articles using the search terms. Initial scan of the title and abstract led to exclusion of duplicates, editorial and conceptual pieces. The process of inclusion and exclusion of studies can be seen in Figure 1. Eight studies were considered eligible after exclusions and had information on both male and female suicides (Andersen, Hawgood, Klieve, Kolves, \& De Leo, 2010; Kim et al., 2006; Meltzer, Griffiths, Brock, Rooney, \& Jenkins, 2008; Mustard et al., 2010; Skegg, Firth, Gray, \& Cox, 2010; Tanaka et al., 2001; van Wijngaarden, 2003; Violanti, 2010). As can be seen in Table 1, six of these were retrospective examinations of mortality databases (Andersen et al., 2010; Kim et al., 2006; Meltzer et al., 2008; Skegg et al., 2010; van Wijngaarden, 2003; Violanti, 2010) and two were based on cohorts (Mustard et al., 2010; Tanaka et al., 2001). All apart from one (Tanaka et al., 2001) reported on multiple occupational groups. Effect measures included ORs (van Wijngaarden, 2003), RRs (Andersen et al., 2010; Kim et al., 2006; Mustard et al., 2010), PMRs (Violanti, 2010), and SMRs (Meltzer et al., 2008; Skegg et al., 2010; Tanaka et al., 2001). 
Figure 2 indicates the pooled results for each of the nine ISCO categories by sex. The pooled RRs were interpreted as the risk of suicide in the category of interest compared to the working-age population. Information regarding $\mathrm{I}^{2}$ and degrees of freedom can be seen directly below the figure.

Across all occupations, males and females had a similar risk of suicide and there were a number of similar patterns between males and females within occupational groups. The highest risk of suicide for both males and females was apparent in community service occupations, such as police (ISCO 5, RR for females 1.95 , 95\% CI 1.02, 3.71; RR for males 1.29, 95\% CI 1.08, 1.55) and military occupations (ISCO 0, RR for females 1.81, 95\% CI 1.41, 2.32; RR for males 1.62, 95\% CI 1.25, 2.11). For both males and females, low risk of suicide was observed in high skill level groups of managers (ISCO 1, RR for males 0.49, 95\% CI 0.28, 0.85; RR for females 0.46, 95\% CI 0.27, 0.79) and clerical support workers (ISCO 4, RR for males 0.71, 95\% CI 0.53, 0.94; RR for females $0.53,95 \%$ CI $0.44,0.64)$. Both females and males had higher risk of suicide in elementary occupations (ISCO 9, RR for males 1.30, 95\% CI 1.16, 1.45; RR for females 1.19; 95\% CI 0.80, 1.76) and skilled agricultural workers (ISCO 6, RR 1.74, 95\% CI 1.21, 2.50), but the small sample sizes for females (RR 1.19, $95 \%$ CI $0.43,3.32$ ) meant that this estimate was not significantly different from the estimate of the general employed population.

There were also some evidence of differences between males and females, but these did not reach statistical significance. Males had a greater risk in ISCO 3 (technicians and associate professionals) (RR 1.3 95\% CI 0.90, 1.87), ISCO 8 (plant and machine operators and ship's deck crew) (RR 1.68; 95\% CI 1.10, 2.55) and ISCO 7 (craft and related trades workers) (RR 1.40, 95\% CI 1.04, 1.89) groups, whereas females had a lower risk compared to the general working age population. By comparison, females had a greater (albeit non-significant) risk of suicide than the general working-age population in ISCO 2 (professionals) (RR 1.14, 95\% CI 0.85, 1.53) while males had a lower risk (RR $0.85,95 \%$ CI 0.67, 1.07).

\section{Discussion}

The meta-analysis presented above suggests that males and females had a similar risk of suicide in several occupational groups. There was also some evidence for gender differences among other groups, but these results were largely non-significant. We did not find support for our first hypothesis, as females did not have significantly elevated suicide rate ratios in low skilled occupational groups. Males appeared to have lower suicide rates in the professional occupational category (which included doctors) while females had higher suicide rates. This suggests some support for our second hypothesis, although we would note that overlapping confidence intervals meant that results were non-significant.

Exposure to violence and familiarity with lethal suicide methods may impact both males and females in similar negative ways in the military and the police. For example, witnessing others being injured or killed, being involved in direct combat and discharging a weapon, and fear of being killed has been related to a higher prevalence of mental health problems among the military (Hoge, Auchterlonie, \& Milliken, 2006). Likewise, being witness to the homicide of fellow officers or other people dying contributes to higher reports of posttraumatic stress among the police force, which in turn contributes to higher suicide ideation (Violanti, 2004). 
Both males and females employed in the police and the military would be familiar with lethal suicide methods, such as firearms, and have ready access to these through their work. Corresponding to this, persons employed in these occupations tend use these as means to end their lives (Skegg et al., 2010). Converse to elevated suicide in these occupations, reduced risk among males and females in high-skilled jobs may be connected to more favourable psychosocial working conditions (Niedhammer et al., 2008), higher income, and educational background.

Poor psychosocial working conditions and socio-economic factors may explain the higher risk for both males and females in elementary occupations (ISCO 9), although we would note small sample sizes for women hindered the ability to observe statistically meaningful differences. At a population level, previous research suggests that depressive symptoms among those employed in lower skilled jobs is in part attributable to their greater exposure to adverse working conditions such as repetitive work, shift work, job strain, and limited social support from work colleagues (Cohidon, Santin, Imbernon, \& Goldberg, 2010). At the same time, male and female suicide among those employed in these occupations may be connected to social, education and income-related disadvantage. This aligns with past research demonstrating elevated suicide rates among those in lower socio-economic groups (Lorant et al., 2003; Morrell, Page, \& Taylor, 2002; Page, Morrell, \& Taylor, 2002; Page, Morrell, Taylor, Carter, \& Dudley, 2006; Pan, Stewart, \& Chang, 2013).

There were a number of occupational categories in which males and females had differing risks of suicide, although results did not reach statistical significance. Notwithstanding this problem, our results suggest that gender modified associations so that females in ISCO 2 occupations (e.g., medical professionals, veterinarians, engineers, dentists, nurses) had a slightly greater risk of suicide. Males were at elevated risk of suicide in manual-trade occupations such as technicians and associate professionals (ISCO 3), machine operators and ship's deck crew (ISCO 8), and craft and related trades workers (ISCO 7) than females. Relatively few studies have examined the reasons underpinning gender differences in occupational suicide risk. Among the few in the area, Hawton et al. (2001) suggests that suicide in females employed in medical related jobs reflects gender role conflict and their minority status comparative to men. More recently, results from the UK (Roberts, Jaremin, \& Lloyd, 2012) argue that males have higher suicide risk in manual occupations because they are more vulnerable to socio-economic disadvantage than females.

The limitations of this review included the small number of studies meeting inclusion criteria, low sample sizes for female suicide in some occupational groups and heterogeneity between studies (Milner et al., 2013). The inability to control for potentially important factors such as socio-economic status is a further problem. However, our previous research has found that the relationship between occupation and suicide holds after controlling for socio-economic factors (Milner et al., 2013). Limitations in the search strategy also may have meant that eligible studies may have been excluded or were screened out of the meta-analytic review. Results were confined to high-income countries, which could affect the generalizability of results.

These potential weaknesses aside, this study suggests that gender alone cannot explain occupational gradients in suicide mortality. Instead, the causes of suicide are differ within occupational groups and represent a multi- 
faceted combination of access to means, personal, demographic and socio-environmental and work-related factors. From an analytic perspective, we suggest that studies on occupational suicide need to examine males and females separately. 


\section{References}

Andersen, K., Hawgood, J., Klieve, H., Kolves, K., \& De Leo, D. (2010). Suicide in selected occupations in Queensland: evidence from the state suicide register. Australian \& New Zealand Journal of Psychiatry, 44(3), 243-249.

Cohidon, C., Santin, G., Imbernon, E., \& Goldberg, M. (2010). Working conditions and depressive symptoms in the 2003 decennial health survey: the role of the occupational category. Social Psychiatry \& Psychiatric Epidemiology, 45(12), 1135-1147.

Forrest, A. D. (2014). Gender Remains Major Confounder. British Journal of Psychiatry, published online January 6, 2014(http://bjp.rcpsych.org/content/203/6/409/reply\#bjprcpsych_el_55126).

Hawton, K., Clements, A., Sakarovitch, C., Simkin, S., \& Deeks, J. J. (2001). Suicide in doctors: a study of risk according to gender, seniority and specialty in medical practitioners in England and Wales, 1979-1995. Journal of Epidemiology \& Community Health, 55(5), 296-300.

Hoge, C. W., Auchterlonie, J. L., \& Milliken, C. S. (2006). Mental health problems, use of mental health services, and attrition from military service after returning from deployment to Iraq or Afghanistan. The Journal of the American Medical Association, 295(9), 1023-1032.

Kim, M. D., Hong, S. C., Lee, S. Y., Kwak, Y. S., Lee, C. I., Hwang, S. W. . . Shin, J. N. (2006). Suicide risk in relation to social class: a national register-based study of adult suicides in Korea, 1999-2001. International Journal of Social Psychiatry, 52(2), 138-151.

Lindeman, S., Laara, E., Hakko, H., \& Lonnqvist, J. (1996). A systematic review on gender-specific suicide mortality in medical doctors. British Journal of Psychiatry, 168(3), 274-279.

Lorant, V., Deliège, D., Eaton, W., Robert, A., Philippot, P., \& Ansseau, M. (2003). Socioeconomic Inequalities in Depression: A Meta-Analysis. American Journal of Epidemiology, 157(2), 98-112. doi: 10.1093/aje/kwf182

Meltzer, H., Griffiths, C., Brock, A., Rooney, C., \& Jenkins, R. (2008). Patterns of suicide by occupation in England and Wales: 2001-2005. British Journal of Psychiatry, 193(1), 73-76.

Milner, A., Spittal, M. J., Pirkis, J., \& LaMontagne, A. D. (2013). Suicide by Occupation: A systematic review and meta-analysis. British Journal of Psychiatry, 203, 409-416.

Morrell, S., Page, A., \& Taylor, R. (2002). Birth cohort effects in New South Wales suicide, 1865-1998. Acta Psychiatrica Scandinavica, 106(5), 365-372.

Mustard, C. A., Bielecky, A., Etches, J., Wilkins, R., Tjepkema, M., Amick, B. C., . . Aronson, K. J. (2010). Suicide mortality by occupation in Canada, 1991-2001. Canadian Journal of Psychiatry, 55(6), 369376.

Niedhammer, I., Chastang, J. F., Levy, D., David, S., Degioanni, S., \& Theorell, T. (2008). Study of the validity of a job-exposure matrix for psychosocial work factors: results from the national French SUMER survey. International Archives of Occupational and Environmental Health, 82(1), 87-97.

Page, A., Morrell, S., \& Taylor, R. (2002). Suicide differentials in Australian males and females by various measures of socio-economic status, 1994-98. Australian \& New Zealand Journal of Psychiatry, 26(4), 318-324.

Page, A., Morrell, S., Taylor, R., Carter, G., \& Dudley, M. (2006). Divergent trends in suicide by socioeconomic status in Australia. Social Psychiatry \& Psychiatric Epidemiology, 41(11), 911-917.

Pan, Y. J., Stewart, R., \& Chang, C. K. (2013). Socioeconomic disadvantage, mental disorders and risk of $12-$ month suicide ideation and attempt in the National Comorbidity Survey Replication (NCS-R) in US. Social Psychiatry \& Psychiatric Epidemiology,48(1), 71-79.

Roberts, S. E., Jaremin, B., \& Lloyd, K. (2012). High-risk occupations for suicide. Psychological Medicine, 43(6), 1231-1240

Skegg, K., Firth, H., Gray, A., \& Cox, B. (2010). Suicide by occupation: does access to means increase the risk? Australian \& New Zealand Journal of Psychiatry, 44(5), 429-434.

StataCorp. (2012). Stata Release 12.1. College Station, Texas StataCorp LP.

Tanaka, H., Nishio, N., Murakami, E., Mukai, M., Kinoshita, N., \& Mor, I. (2001). Mortality and causes of death among Japanese school personnel between 1992 and 1996. Journal of Occupational Health, 43(3), 129-135.

van Wijngaarden, E. (2003). An exploratory investigation of suicide and occupational exposure. Journal of Occupational and Environmental Medicine, 45(1), 96-101.

Violanti, J. M. (2004). Predictors of police suicide ideation. Suicide and Life-Threatening Behavior, 34(3), $277-$ 283.

Violanti, J. M. (2010). Suicide or undetermined? A national assessment of police suicide death classification. International Journal of Emergency Mental Health, 12(2), 89-94. 
Windfur, K., \& Kapur, N. (2011). Interntational Perspectives on the epidemiology and aetiology of suicide and self-harm. In R. C. O'Connor, S. Platt \& J. Gordon (Eds.), International Handbook of Suicide Prevention: Research, Policy and Practice (pp. 27-58). United Kingdom: Wiley-Blackwell. 
Figure 1. Selection of studies for meta-analysis.

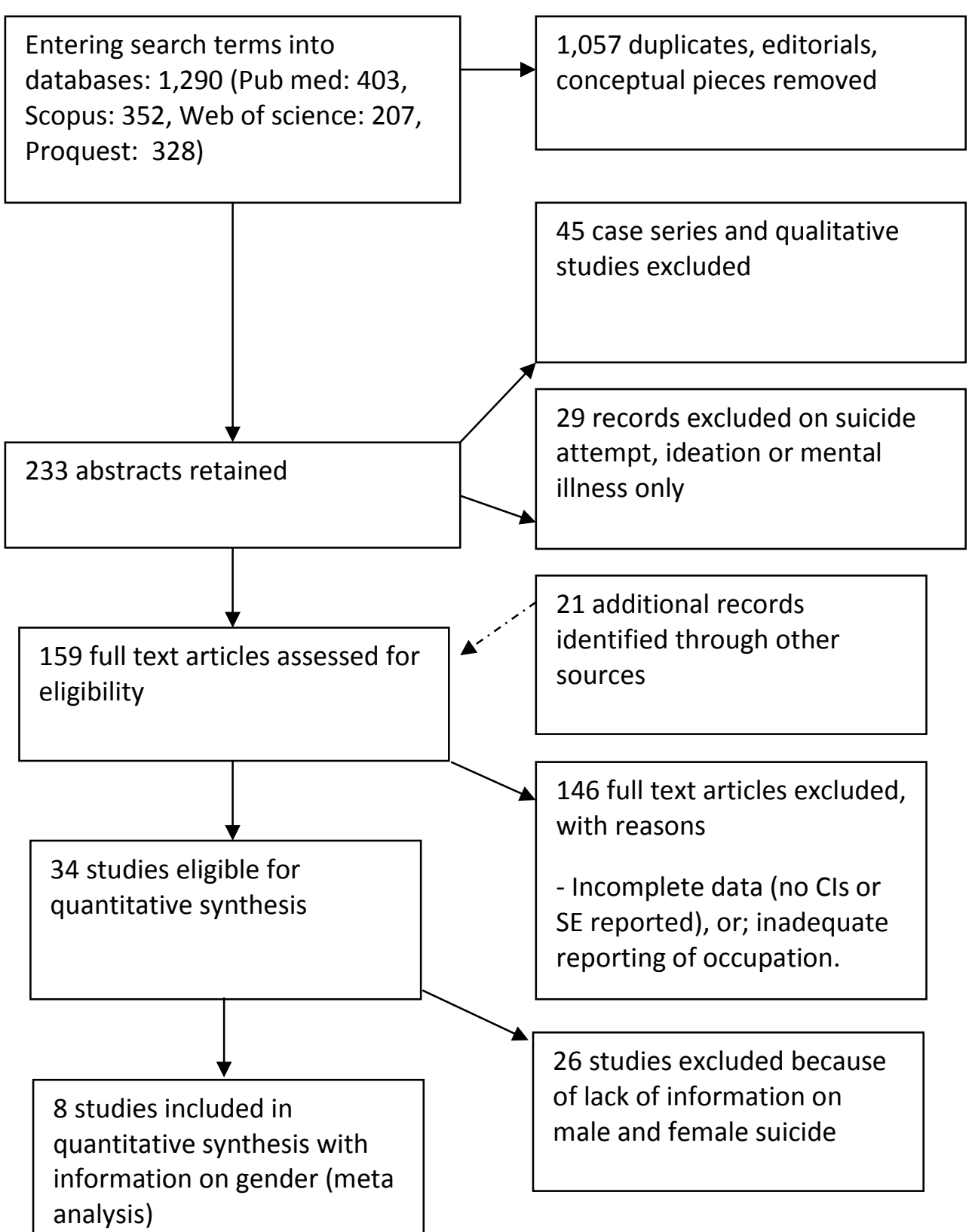


Table 1. Description of studies on occupation and suicide included in the meta-analysis.

\begin{tabular}{|c|c|c|c|c|c|c|c|c|c|}
\hline Study & Design & Location & Sex & $\begin{array}{l}\text { Adjusted } \\
\text { for socio- } \\
\text { economic } \\
\text { factors }\end{array}$ & $\begin{array}{l}\text { Time } \\
\text { period }\end{array}$ & $\begin{array}{l}\text { Number of } \\
\text { observations } \\
\text { (occupations reported) }\end{array}$ & $\begin{array}{l}\text { ISCO } 2008 \\
\text { major } \\
\text { categories } \\
\text { reported on }\end{array}$ & $\begin{array}{l}\text { Comparison } \\
\text { group }\end{array}$ & $\begin{array}{l}\text { Effect } \\
\text { measure }\end{array}$ \\
\hline $\begin{array}{l}\text { Andersen et al., } \\
2010^{8}\end{array}$ & $\begin{array}{l}\text { Case-control } \\
\text { (information } \\
\text { obtained from } \\
\text { retrospective } \\
\text { mortality } \\
\text { databases) }\end{array}$ & $\begin{array}{l}\text { Queensland, } \\
\text { Australia }\end{array}$ & $\begin{array}{l}\text { Male and } \\
\text { female }\end{array}$ & No & $\begin{array}{l}1990- \\
2006\end{array}$ & $\begin{array}{l}12 \text { observations, } \\
\text { multiple occupations }\end{array}$ & $2,6,8,9$ & $\begin{array}{l}\text { Suicide rate in the } \\
\text { employed } \\
\text { population }\end{array}$ & RRs \\
\hline Kim et al., $2006^{9}$ & $\begin{array}{l}\text { Case-control } \\
\text { (information } \\
\text { obtained from } \\
\text { retrospective } \\
\text { mortality } \\
\text { databases) } \\
\end{array}$ & Korea & $\begin{array}{l}\text { Male and } \\
\text { female }\end{array}$ & Yes & $\begin{array}{l}1999- \\
2001\end{array}$ & $\begin{array}{l}19 \text { observations, } \\
\text { multiple }\end{array}$ & $\begin{array}{l}2,3,4,5,6 \\
7,8,9,0\end{array}$ & $\begin{array}{l}\text { Suicides among } \\
\text { legislators, senior } \\
\text { officials and } \\
\text { managers. }\end{array}$ & OR \\
\hline$\underset{10}{\text { Meltzer et al., } 2008}$ & $\begin{array}{l}\text { Case-control } \\
\text { (information } \\
\text { obtained from } \\
\text { retrospective } \\
\text { mortality } \\
\text { databases) } \\
\end{array}$ & UK \& Wales & $\begin{array}{l}\text { Male and } \\
\text { female }\end{array}$ & No & $\begin{array}{l}2001- \\
2005\end{array}$ & $\begin{array}{l}18 \text { observations, } \\
\text { multiple }\end{array}$ & $2,3,4,5,7,8$ & $\begin{array}{l}\text { General working- } \\
\text { age population }\end{array}$ & SMR \\
\hline $\begin{array}{l}\text { Mustard et al., } \\
2010^{11}\end{array}$ & Cohort & Canada & $\begin{array}{l}\text { Male and } \\
\text { female }\end{array}$ & No & $\begin{array}{l}1991- \\
2001\end{array}$ & $\begin{array}{l}10 \text { observations, } \\
\text { multiple }\end{array}$ & $1,2,7,9$ & $\begin{array}{l}\text { Suicide rate in all } \\
\text { occupations. }\end{array}$ & RRs \\
\hline$\underset{12}{\text { Skegg et al., } 2010}$ & $\begin{array}{l}\text { Case-control } \\
\text { (information } \\
\text { obtained from } \\
\text { retrospective } \\
\text { mortality } \\
\text { databases) } \\
\end{array}$ & New Zealand & $\begin{array}{l}\text { Male and } \\
\text { female }\end{array}$ & No & $\begin{array}{l}1973- \\
2004\end{array}$ & $\begin{array}{l}18 \text { observations, } \\
\text { multiple }\end{array}$ & $2,5,6,0$ & $\begin{array}{l}\text { General working- } \\
\text { age population }\end{array}$ & SMR \\
\hline $\begin{array}{l}\text { Tanaka et al., } 2001 \\
13\end{array}$ & $\begin{array}{l}\text { Occupational } \\
\text { cohort }\end{array}$ & Japan & $\begin{array}{l}\text { Male and } \\
\text { female }\end{array}$ & No & $\begin{array}{l}1992- \\
1996\end{array}$ & $\begin{array}{l}6 \text { observations, school } \\
\text { personnel }\end{array}$ & 2 & $\begin{array}{l}\text { General working- } \\
\text { age population, all } \\
\text { workers, peer } \\
\text { group }\end{array}$ & SMR \\
\hline
\end{tabular}




\begin{tabular}{|c|c|c|c|c|c|c|c|c|c|}
\hline $\begin{array}{l}\text { Van Wijngaarden } \\
2003\end{array}$ & $\begin{array}{l}\text { Case-control } \\
\text { (information } \\
\text { obtained from } \\
\text { retrospective } \\
\text { mortality } \\
\text { databases) }\end{array}$ & USA & $\begin{array}{l}\text { Male and } \\
\text { female }\end{array}$ & Yes & $\begin{array}{l}1991 \text { and } \\
1992\end{array}$ & $\begin{array}{l}21 \text { observations, } \\
\text { multiple }\end{array}$ & $\begin{array}{l}2,5,6,7,8, \\
9,0\end{array}$ & 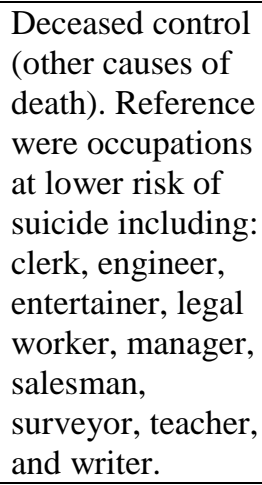 & OR \\
\hline Violanti $2010^{15}$ & $\begin{array}{l}\text { Case-control } \\
\text { (information } \\
\text { obtained from } \\
\text { retrospective } \\
\text { mortality } \\
\text { databases) }\end{array}$ & USA & $\begin{array}{l}\text { Male and } \\
\text { female }\end{array}$ & No & $\begin{array}{l}1950- \\
1990\end{array}$ & $\begin{array}{l}11 \text { observations, } \\
\text { police and military }\end{array}$ & 5,0 & $\begin{array}{l}\text { The proportion of } \\
\text { suicides in the } \\
\text { working-age } \\
\text { general } \\
\text { population }\end{array}$ & PRM \\
\hline
\end{tabular}

Notes: SMR = standardised mortality ratios; RRs = rate ratios; OR= odds ratio; SMR = standardised mortality ratios; PRM= proportionate mortality ratios. ISCO 2008 major categories: $0=$ Military; $1=$ Managers, senior officials and legislators; $2=$ Professionals; $3=$ Technicians and associate professionals; $4=$ Clerks; $5=$ Service and sales workers; $6=$ Skilled agricultural and fishery workers; $7=$ Craft and related trades workers; $8=$ Plant and machine operators, and assemblers; $9=$ Elementary occupations. 
Figure 2. Rate-ratios with confidence intervals (95\% significance) from meta-analyses on occupational suicide, stratified by males, females and all persons, using the major codes from the International Standard Classification of Occupations (ISCO) (version 2008) as occupational groups.

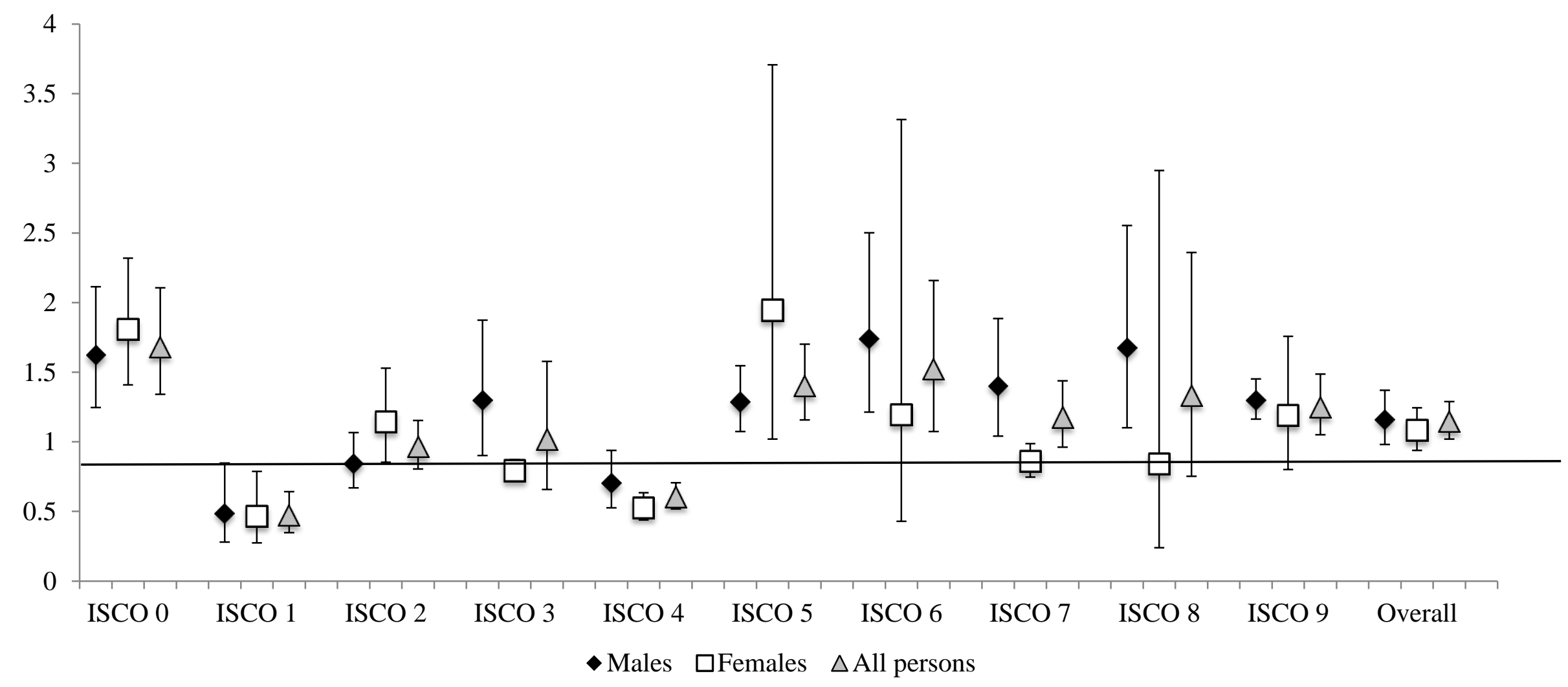

Notes: $\quad$ ISCO 0 (Military) $\mathrm{I}^{2}=89.90 \%$, p <0.001; ISCO 1 (Managers, senior officials and legislators) $\mathrm{I}^{2}=94.60 \%$, p $<0.001 ;$ ISCO 2 (Professionals) $\mathrm{I}^{2}=90.70 \%$, $\mathrm{p}<0.001$;

ISCO 3 (Technicians and associate professionals) $\mathrm{I}^{2}=73.40 \%, \mathrm{p}=0.023$; ISCO 4 (Clerical workers) $\mathrm{I}^{2}=84.60 \%$, $\mathrm{p}<0.001$; ISCO 5 (Service personnel such as police and sales workers) $\mathrm{I}^{2}=92.70 \%, \mathrm{p}<0.001$; ISCO 6 (Skilled agricultural and fishery workers) $\mathrm{I}^{2}=93.70 \%, \mathrm{p}<0.001 ;$ ISCO 7 (Craft and related trades workers) $\mathrm{I}^{2}=84.80 \%, \mathrm{p}<0.001$;

ISCO 8 (Plant and machine operators, and assemblers) $\mathrm{I}^{2}=93.30 \%, \mathrm{p}<0.001$; ISCO 9 (Elementary occupations such as labourers and cleaners) $\mathrm{I}^{2}=93.40 \%$, $<<0.001 ;$ Overall $\mathrm{I}^{2}=98.20 \%, \mathrm{p}<0.001$. 